CT ガイド下マーカーが気管支を経由して消化管に迷入した 2 例

油原 信二 $* 1 * 2$, 河野 匡 ${ }^{*} 1 * 2$, 藤森 賢 $* 2$

鈴木聡一郎 $* 2$, 菊永晋一郎*2

\begin{abstract}
要 旨
ナイロン糸付きマーカーによる CT ガイド下マーキングでは, 気胸, 肺内出血, 空気塞栓などの合併症が知られる. 今回, マーカーが気管支を経由し消化管に迷入した 2 例を経験したので報告する. 症例 1 : 左上葉結節に対して手術前日にマーキ ングを施行したが, 術中, 胸腔内にマーカーを認めなかった. 病変は触知し得たため部分切除を施行. CT T゙は下行結腸にマー カーを認め, 第 3 病日に便中へ排出された. 症例 2 : 右中葉結節に対して手術前日にマーキングを施行. 処置後の Xp でマー カーを認めず, CT で小腸内に認めた. 腫瘍を触知し得たため中葉部分切除を施行. 腺癌の迅速診断のため中葉切除を施行し た. 第 3 病日の腹部 Xp でマーカーは消失し，CT でも腸管内に認めず，排出されたと判断した．マーカーが気管支から喀出 され消化管に迷入したと考えられ，気管支を避けたマーカー留置，付属ナイロン糸の皮膚への固定が迷入を避けるために効 果的と考えられた.
\end{abstract}

索引用語 : CT ガイド下マーキング, 胸腔鏡手術, 合併症, 消化管内迷入 computed tomography-guided localization, thoracoscopic surgery, complication, migration into the digestive tract

\section{緒言}

ナイロン糸付きマーカーを用いた CT ガイド下マーキ ングは, 触知困難な肺結節に対する胸腔鏡下肺切除術に おいて, 局在同定法として有用である ${ }^{1,2)}$. 一方, 気胸や 肺内出血の合併症が報告されており ${ }^{3.7)}$, 空気塞栓は稀で はあるが致死的な合併症であり注意が必要である ${ }^{8)}$. 当科 では肺腫瘍マーキング用ガイディングマーカーシステ ム ${ }^{\mathrm{TM}}$ （株式会社八光, 長野県千曲市) を使用している. 先端のフックの部分のみ金属性であり, ナイロン糸が フックに繋がるという構造を成している. 手術室や CT 室の混雑を考慮し, 全例手術前日午後にCT ガイド下 マーキングを行い, マーカーを留置している. 今回, ナ イロン糸付きマーカーが区域気管支を経由して喀出され た後, 誤飲により消化管内に迷入するという稀な合併症

\footnotetext{
*1新東京病院呼吸器外科

*2虎の門病院呼吸器センター外科

原稿受付 2020年 8 月31日

原稿採択 2021年 3 月 24 日
}

を 2 例経験したので報告する.

\section{症例}

\section{症例 1}

患 者：61 歳男性.

主 訴：なし。

既往歴：胃癌に対して開腹幽門側胃切除 + Roux-en-Y 法による再建を施行.

現病歴 : X -3 年に胃癌に対して上記手術を施行. 術前 の CTで多発肺結節を認めており経過観察を継続してい たが，X 年の CT で左上葉結節が増大傾向を示したため 診断目的に手術の方針となった.

生活歴：20 本/日，32 年の契煙歴があり 52 歳より禁 煙. 粉塵暴露歴なし.

血液検査所見：軽度の肝機能異常を認めるのみ. 腫瘍 マーカーは, CEA $7.0 \mu \mathrm{g} / \mathrm{L}$, CYFRA $4.4 \mu \mathrm{g} / \mathrm{L}$ と上昇を認 めた。

胸部 Xp ：左上肺野に多発する結節影を認めた（Fig. 1a). 


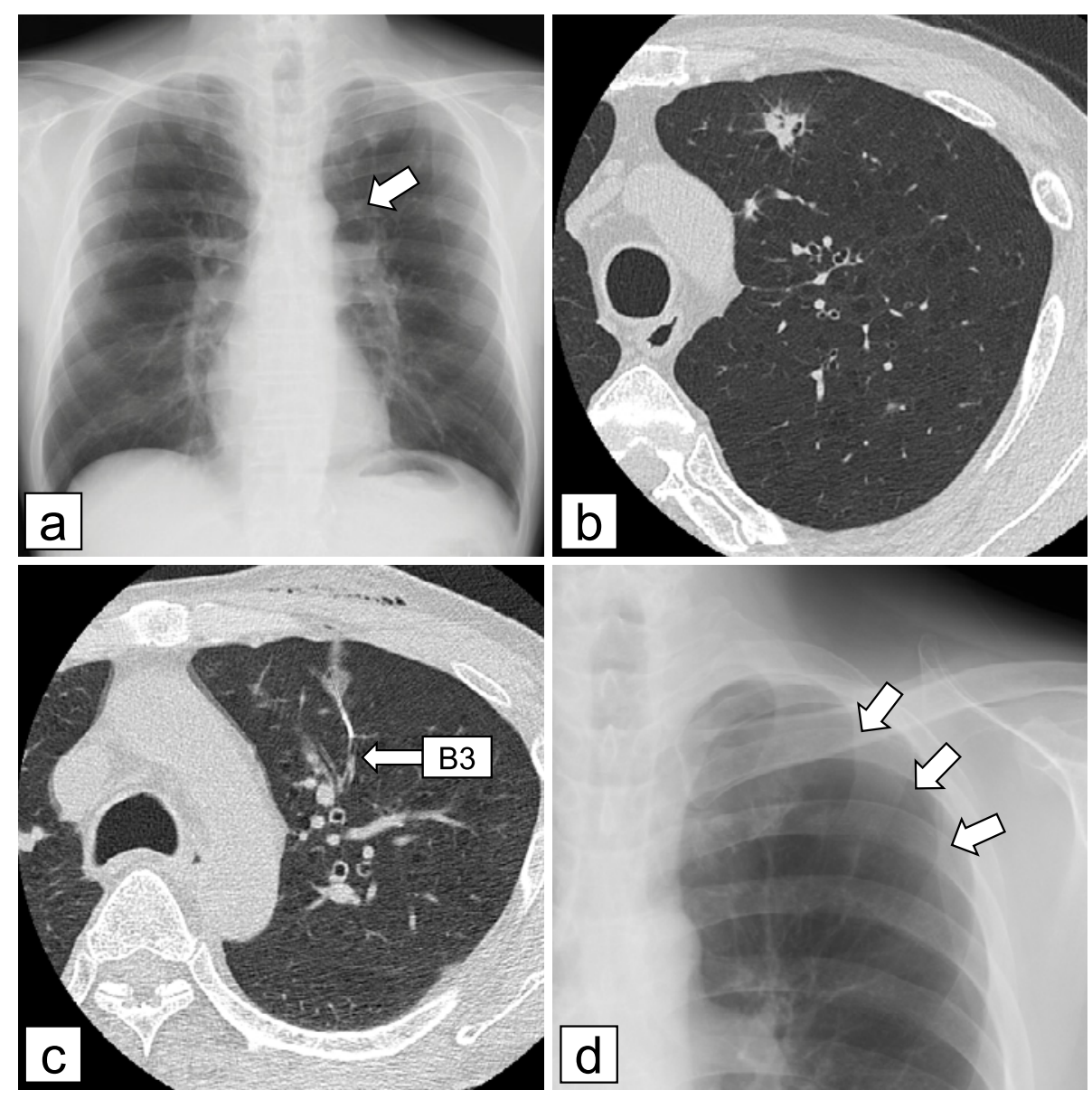

Fig. 1 (a) A preoperative chest radiograph showed multiple nodules in the left upper lung field. (b) Preoperative CT showed a 13-mm irregular nodule in segment 3 of the left upper lobe. (c) CT showed the marker near the anterior segmental bronchus. (d) A chest radiograph after placement of the marker showed slight pneumothorax (arrow).

胸部 CT : X-3 年より両肺に小結節が多発していた. 左上葉 S3に $13 \times 11 \mathrm{~mm}$ 大の充害型結節を認め, 同病変 のみ経時的に増大傾向を認めた（Fig. 1b).

以上より炎症性の肺病変を疑い, 診断目的に3-port 胸腔鏡下左上葉部分切除を予定した. 触知困難と予想し, 手術前日に CT ガイド下マーキングを施行した. 仰臥位 で腹側からマーカーを刺入. B3 とやや近接していた (Fig. 1c). 処置後 30 分に撮影した胸部 Xp では軽度の肺 虚脱を認めた (Fig. 1d).

手術所見：マーキングの翌日, 右側臥位で 3-port 胸腔 鏡手術を開始した. マーカーを検索するも発見に至らず, 側臥位のまま術中胸部 Xp を施行したが胸腔内にマー カーを認めなかった。病変は触知し得たため, 左上葉部 分切除を施行. 術中迅速病理検査では器質化肺炎の診断
であり, 手術終了とした. 手術時間 131 分, 出血 $100 \mathrm{ml}$. 術後経過 : 全身麻酔下で体位を仰臥位に移して腹部 $\mathrm{Xp}$ を施行したところ, 左上腹部にマーカーを認めた (Fig. 2a). 幽門側胃切除後であるため残胃内にマーカー が存在している可能性を考慮し, 全身麻酔下に上部消化 管内視鏡を施行したが, 発見できなかった. 抜管後にCT を施行したところ，下行結腸にマーカーを認めた（Fig. $2 b)$. 消化器内科医にコンサルトし, 緊急処置は行わず便 中に排出されるのを待つ方針とした. 同日夕方より食事 を再開し，通常通りの術後管理とした。第 1 病日の腹部 Xp ではマーカーの位置は不変であったが (Fig. 2c), 第 2 病日には下腹部に移動し (Fig. 2d), 第 3 病日に便中に マーカーを発見した，消化管出血及び穿孔を示唆する所 見なく経過し,やや肺瘦が遷延したが第 11 病日に退院し 


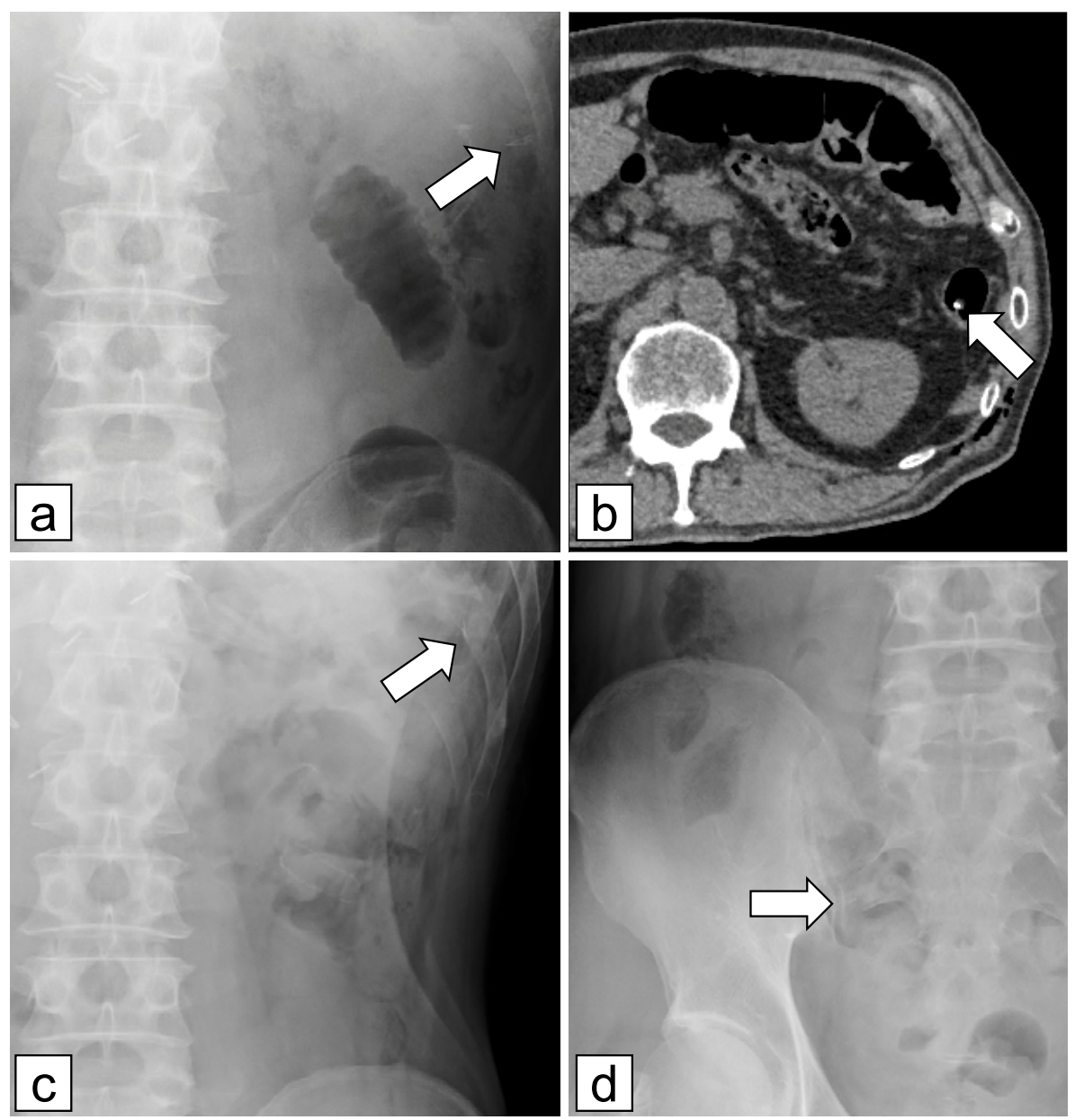

Fig. 2 (a) An abdominal radiograph immediately after surgery showed the marker (arrow) in the left upper quadrant. (b) Postoperative CT showed the marker (arrow) in the descending colon. (c) On the first postoperative day, the marker (arrow) had not moved. (d) On the second postoperative day, the marker (arrow) had moved to the lower quadrant.

た. 最終病理診断は器質化肺炎であった.

\section{症例 2}

患 者: 70 歳女性.

主 訴：なし。

既往歴: X-15 年, 左乳癌に対して左乳房全摘術を施 行. 術後 5 年間ホルモン療法を施行した.

現病歴 : X 年, 検診の胸部 Xp で右中肺野の結節影を 指摘され, 前医で胸部 CT 及び PET-CT を施行した. 右 中葉に $13 \times 12 \mathrm{~mm}$ 大の充実型結節を認め, FDG 異常集 積も認められた。悪性腫瘍が疑われ, 手術目的に当科紹 介となった。

生活歴： 20 本/日, 35 年の喫煙歴があり 55 歳より禁 煙. 粉塵暴露歴なし.
血液検查所見 : 軽度の貧血のみ. 乳癌, 肺癌の腫瘍マー カーは全て正常範囲内であった.

胸部 Xp : 右中肺野に $1 \mathrm{~cm}$ 大の結節影を認めた（Fig. 3a).

胸部 CT : 右中葉 S4に $13 \times 12 \mathrm{~mm}$ 大の充実型結節を 認め, spiculaを伴っていた. また, 主病変に隣接して 4 $\times 3 \mathrm{~mm}$ 大の結節を認めた. 明らかなリンパ節腫大, 胸水 を認めなかった（Fig. 3b）.

以上ょり, 右中葉肺癌疑いcT1bN0M0 stageIA2 (UICC8) と診断. 右中葉部分切除を先行し, 術中病理で 原発性肺癌と診断された場合は右中葉切除 +ND2a-2 を 施行する方針とした，触知困難と考え，手術前日に仰卧 位で腹側より CT ガイド下マーキングを施行. マーカー 


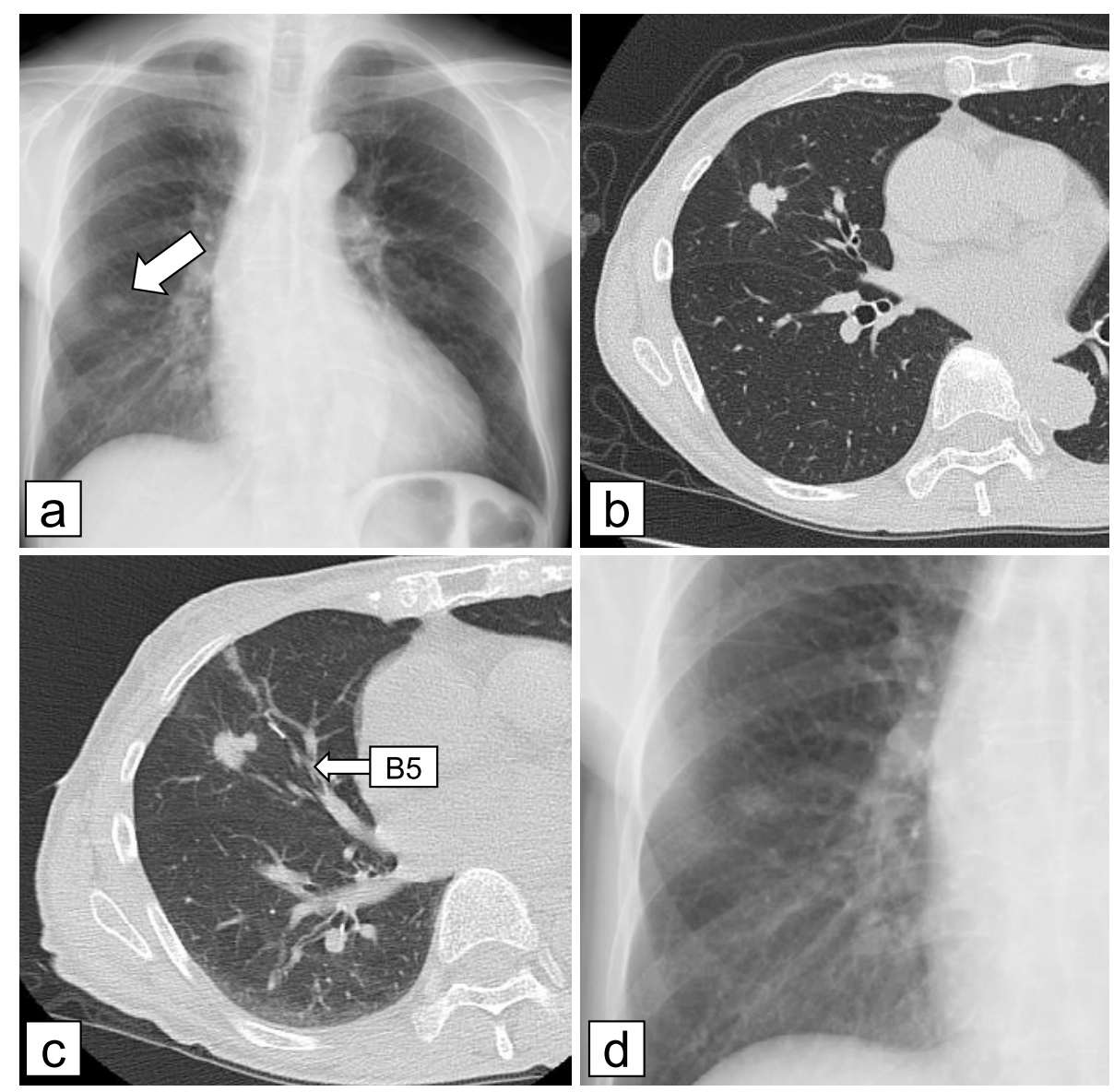

Fig. 3 (a) A preoperative chest radiograph showed a 1-cm nodule (arrow) in the right middle lung field. (b) Preoperative CT showed a 13-mm spiculated nodule in segment 4 of the right middle lobe. (c) CT showed the marker near the medial segmental bronchus. (d) A chest radiograph after the procedure showed no marker.

は予定したより深い位置に認められ, B5に近接していた (Fig. 3c). 処置後 30 分に胸部 Xp を施行したが, 肺野に マーカーを認めなかった (Fig. 3d)，直後にCT を施行し たところ, 小腸内にマーカーを認めた (Fig. 4a). 消化器 内科医にコンサルトした結果, 同日の夕食は中止, 飲水 のみとして経過観察し，翌日の手術は予定通り施行する 方針とした.

手術所見：左側臥位で 3-port 胸腔鏡手術を開始した. 腫瘍は触知し得たため, 中葉部分切除を施行. 術中病理 で腺癌と診断されたため, 中葉切除 $+\mathrm{ND} 2 \mathrm{a}-2$ を施行し た. 手術時間 240 分, 出血 $136 \mathrm{ml}$.

術後経過: 手術当日夕方より低残渣食を開始. 腹部症 状なく経過し, 食事は連日全量摂取した. 第 1 病日の腹 部 Xp では右下腹部にマーカーを認めた (Fig. 4b). 肺瘦
を認めず経過し, 同日胸腔ドレーンを抜去した. 第 2 病 日の腹部 Xp では左上腹部にマーカーは移動したが (Fig. 4c), 第 3 病日のXpでは確認できなかった（Fig. 4d). 第 4 病日の Xp でもマーカーを認めないため, CT を施行したところ腸管内にマーカーの遺残は認めなかっ た. 便中への排出を確認できなかったが, マーカーは体 外に排出されたと判断し同日退院となった，免疫染色の 結果, 乳癌の肺転移と診断されたため, 紹介医のもとで 加療を継続する方針となった。

\section{考察}

腫瘍の局在同定法としては VAL-MAP ${ }^{9)}$ やリピオドー ルマーキング10) などの方法も報告されているが, ナイロ ン糸付きマーカーは簡便かつ安価であるため広く選択さ 

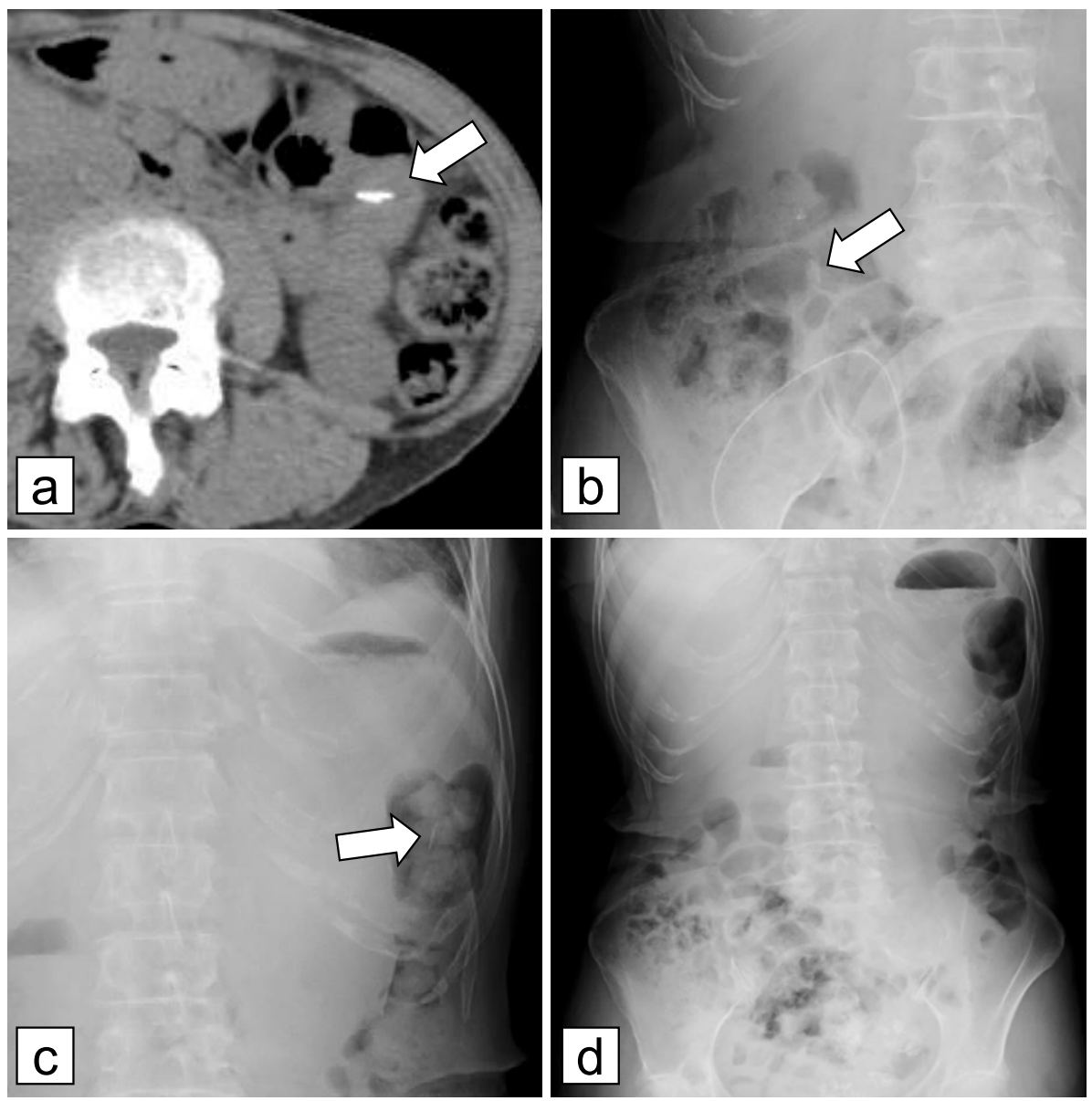

Fig. 4 (a) CT showed the marker (arrow) in the small intestine. (b) On the first postoperative day, an abdominal radiograph showed the marker (arrow) in the right lower quadrant. (c) On the second postoperative day, the marker (arrow) had moved to the left upper quadrant. (d) On the third postoperative day, the marker was not detected.

れている，海外では，全て金属部分から成るフックワイ ヤー針を手術直前にCT ガイド下に留置し, 針が体外に 露出したまま手術室に移動する方法が主流である。主な 合併症としては，気胸が $7.6 〜 56.2 \%$, 肺内出血が5.0〜 $34.8 \%$ と報告されている ${ }^{3.7}$. 空気塞栓は $0.12 \sim 0.49 \%$ と 稀だが致死的になり得る合併症であり, 特に注意が必要 である ${ }^{8}$. CT ガイドにより経皮的に肺内にリピオドール やマイクロコイルを留置する方法では, 肺内に針が留置 されないメリットはあるものの, 空気塞栓及び異物によ る塞栓の懸念は残る ${ }^{10}$.11). VAL-MAP などの経気管支的 な方法では空気塞栓のリスクを回避可能と考えられる が, 人員や設備による制限のため, 施設によっては施行 が難しい.11). 当科では気管支鏡専門医が不在であり，ま た内視鏡室を自由に使用できる環境にないため, 慎重な
症例選択と患者への十分な説明を行った上でフックワイ ヤー針を使用している．当科で 2011 年 6 月から 2017 年 12 月に施行した 522 例, 584 病変に対する CT ガイド下 マーキングに打ける合併症は，気胸 315 例 $(60.3 \%)$ ，脱 気を要した気胸 12 例 (1.9\%), 肺内出血 62 例 (11.9\%) で あり，空気塞栓は認めなかった，海外の報告における， 針を刺入したまま手術室に移動する方法と比較すると， 当科の処置では前日にマーキングを行うため気胸を診断 する割合が増加していると思われる，森田ら ${ }^{12)}$ は気管支 動脈に留置したコイルが, 気管支に穿破して喀出された という報告をしているが，肺実質に刺入したマーカーが 気管支を経由して消化管内へ迷入したという報告は，検 索し得た限りでは広瀬ら ${ }^{13)}$ の会議録のみであった。

当科では腫瘍触知の際に胸腔内に指を入れない完全胸 
腔鏡下手術を施行しており, 術前に CT ガイド下マーキ ングを行う基準として, (1)pureGGO, (2)solid であっても 腫瘍径程度胸膜から離れている深部結節, (3)高度の癒着 が予想されること,の 3 点を考慮している. 当科では CT ガイド下マーキングを施行した後, 約 30 分後に全例胸部 Xp を施行し, 気胸や出血の有無を確認している. 症例 1 では手術中にこの Xp を見直したところ, マーカーは胸 腔内に確認できなかった. マーキング施行後に夕食を摂 取しており, 気管支を経由して喀出され, 食物と共に無 意識に誤飲されたものと考えられた。患者本人に問診を 行なったが, マーカーの喀出や誤飲についての自覚症状 は認められなかった．本症例は幽門側胃切除後であり， 食物が胃内に留まりづらいこともマーカーが下行結腸ま で進んだ一因と考えられた，症例 2 ではこの際の反省か ら, 処置 30 分後の Xp で既に胸腔内にマーカーが存在し ないことを認識し, 直後にCT を施行した. 処置後 2 時間 程度しか経過しておらず, 夕食摂取前であったが, マー カーは既に小腸まで移動していた。自覚症状は無く, 無 意識下に喀出, 誤飲していた。

広瀬ら ${ }^{13)}$ は，手術開始時に認識していたマーキング針 を術中に見失ったと報告している. 第 1 病日の胸部 Xp で縦隔付近に針を認め, 上部消化管内視鏡により胃内の 針を摘除した. 一方, 当科の 2 症例ではいずれもトライ ツ勒带を超えた消化管内にマーカーを認めた。 消化器内 科医にコンサルトし, 消化管穿孔や出血のリスクは低い と判断し経過観察とした。当科における通常の術後管理 に則り, 手術当日夕方より食事を再開した。 症例 1 では 第 3 病日に便中にマーカーを確認したが, 症例 2 では便 中への排泄を確認できなかったため退院前に CT を施行 し，体内にマーカーが遺残していないことを確認した。 いずれも腹部の合併症無く経過し, 退院した。

CT ガイド下マーキング施行後の胸部 Xp では, 肺の 虚脱度や出血の有無に加えて, 必ずマーカーの位置を確 認することが重要である，また，マーカーの刺入経路を 検討する際, 肋骨や腫瘍, 血管との位置関係のみならず, 気管支との位置関係にも留意する必要があると思われ た. 本合併症を経験して以降, マーカー付属のナイロン 糸を皮膚にテープで固定することで迷入を予防してい る.この際, 肺の虚脱によりマーカーが脱落することを 防ぐため, 数 $\mathrm{cm}$ 程度の余裕を持たせた上で皮虐に固定 するよう工夫している，また，本症例では触知不能であ るリスクを考慮してCT ガイド下マーキングを施行した
が，結果的にはいずれも触知可能であった，更なる慎重 な症例選択に留意し，また症例によっては指による触知 を考慮すべきであると考えられた。

\section{結語}

CT ガイド下マーキング施行後, ナイロン糸付きマー カーが気管支を経由して消化管内に迷入した 2 例を経験 したので報告した.

\section{利 益相 反}

本論文について申告する利益相反はない.

\section{文献}

1. Plunkett MB, Peterson MS, Landreneau RJ, Ferson PF, Posner MC. Peripheral pulmonary nodules: Preoperative percutaneous needle localization with CT guidance. Radiology 1992; 185: 274-6.

2. Mack MJ, Gordon MJ, Postma TW, Berger MS, Aronoff RJ, Acuff TE, et al. Percutaneous localization of pulmonary nodules for thoracoscopic lung resection. Ann Thorac Surg 1992; 53: 1123-4.

3. Ichinose J, Kohno T, Fujimori S, Harano T, Suzuki S. Efficacy and complications of computed tomographyguided hook wire localization. Ann Thorac Surg 2013; 96: 1203-8.

4. Iguchi T, Hiraki T, Gobara H, Fijiwara H, Matsui Y, Miyoshi S, et al. CT fluoroscopy-guided preoperative short hook wire placement for small pulmonary lesions: evaluation of safety and identification of risk factors for pneumothorax. Eur Radiol 2016; 26: 114-21.

5. Gruber-Rouh T, Naguib NNN, Beeres M, Kleine P, Vogl TJ, Jacobi V, et al. CT-guided hook-wire localisation prior to video-assisted thoracoscopic surgery of pulmonary lesions. Clin Radiol 2017; 72: 898.e7-11.

6. Seo JM, Lee HY, Kim HK, Choi YS, Kim J, Shim YM, et al. Factors determining successful computed tomography-guided localization of lung nodules. J Thorac Cardiovasc Surg 2012; 143: 809-14.

7. Suzuki K, Shimohira M, Hashizume T, Ozawa Y, Sobue $\mathrm{R}$, Mimura M, et al. Usefulness of CT-guided hookwire marking before video-assisted thoracoscpic surgery for small pulmonary lesions. J Med Imaging Radiat Oncol 
2014; 58: 657-62.

8. Yi JH, Choi PJ, Bang JH, Jeong SS, Cho JH. Systemic air embolism after computed tomography-guided hook wire localization: two case reports and literature review. J Thorac Dis 2018; 10: E59-64.

9. Sato M, Kuwata T, Yamanashi K, Kitamura A, Misawa $\mathrm{K}$, Imashimizu K, et al. Safety and reproducibility of virtual-assisted lung mapping: a multicentre study in Japan. Eur J Cardiothorac Surg 2017; 51: 861-8.

10. Nomori H, Horio H, Naruke T, Suemasu K. Fluoroscopyassisted thoracoscopic resection of lung nodules marked with lipiodol. Ann Thorac Surg 2002; 74: 170-3.

11. 佐藤雅昭. 小型肺癌の術中局在同定法一術前マーキング 法と virtual-assisted lung mapping一. 肺癌 2014; 54: 83542.

12. 森田あかね, 駒瀬裕子, 池原瑞樹, 石田 明, 山口裕礼, 石橋令臣, 他. 気管支動脈塞栓術後, コイルが喀出された 蔓状血管腫の 1 例. 気管支学 2011; 33: 114-8.

13. 広瀬敏幸, 河北直也, 住友正幸, 松岡 永. CT ガイド下 マーキング針が気管支を経由し，気管から食道内へと迷 入した 1 例. 日呼外会誌 2014; 28: S15.

\title{
Two cases of short hook wire migration into the digestive tract through the bronchus after computed tomography-guided localization
}

\author{
Shinji Yuhara*1*2, Tadasu Kohno*1*2, Sakashi Fujimori*2 \\ Souichiro Suzuki*2, Shinichiro Kikunaga*2 \\ ${ }^{* 1}$ Department of Thoracic Surgery, New Tokyo Hospital, Japan \\ ${ }^{* 2}$ Department of Thoracic Surgery, Respiratory Center, Toranomon Hospital, Japan
}

The common complications after preoperative computed tomography-guided localization are pneumothorax and intrapulmonary hemorrhage. Air embolism is known as a rare but potentially fatal complication. We report two cases of short hook wire with nylon thread (marker) migration into the digestive tract through the bronchus. Case 1: The marker was placed on the day before surgery for a nodule in the left upper lobe. A chest radiograph taken after marking showed a slight pneumothorax. Although we could not find the marker in the thoracic cavity during surgery, we performed partial resection, because the nodule was palpable. Computed tomography revealed the marker in the descending colon. On the third postoperative day, it was found in the stool. Case 2: The marker was placed on the day before surgery for a nodule in the right middle lobe. A chest radiograph taken after the procedure showed no marker. We performed emergent computed tomography and located the marker in the small intestine. On the next day, surgery was performed as scheduled. The nodule was palpable; therefore, we initially performed partial resection. As the intraoperative pathological diagnosis was adenocarcinoma, we performed middle lobectomy. On the third postoperative day, an abdominal radiograph could not detect the marker. Because computed tomography could not reveal the marker in the colorectum on the fourth postoperative day, we considered that it had been discharged from body. In the two cases, the markers were expectorated through the bronchus and migrated into the digestive tract by unconscious swallowing. When performing computed tomography-guided localization, we should avoid peripheral bronchus and fix a nylon thread attached to a marker to the skin. 